The FASEB Journal express article 10.1096/fj.02-0033fje. Published online April 23, 2002.

\title{
C5a receptor and thymocyte apoptosis in sepsis
}

Niels C. Riedemann, Ren-Feng Guo, Ines J. Laudes, Katie Keller, Vidya J. Sarma, Vaishalee Padgaonkar, Firas S. Zetoune, Peter A. Ward

Department of Pathology, University of Michigan Medical School, Ann Arbor, MI 48109

Corresponding author: Peter A. Ward, Department of Pathology, University of Michigan Medical School, 1301 Catherine Road Ann Arbor, Michigan 48109-0602. E-mail: pward@umich.edu

\section{ABSTRACT}

In sepsis, apoptosis occurs in many different organs. The mediators responsible for induction of apoptosis are not clearly known, although there are some suggestions that C5a and the C5a receptor (C5aR) might be directly linked to apoptosis. In the cecal ligation/puncture (CLP) model of sepsis in rats, apoptosis occurs early in a variety of organs, especially in the thymus. We demonstrate that thymocytes from normal rats show specific, saturable, and high affinity binding of ${ }^{125}$ I-labeled recombinant rat C5a. C5a binding to thymocytes was significantly increased $3 \mathrm{~h}$ after CLP and also when thymocytes from normal rats were first incubated in vitro with lipopolysaccharide (LPS) or IL-6. The expression of C5aR mRNA in thymocytes was markedly increased 3, 6, and $12 \mathrm{~h}$ after CLP and increased similarly when normal thymocytes were first exposed to LPS or IL-6 in vitro. Thymocytes obtained 2 or $3 \mathrm{~h}$ after CLP and exposed in vitro to C5a, but not normal thymocytes, underwent increased apoptosis, as demonstrated by annexin-V binding, coinciding with increased activation of caspases 3, 6, and 8. These data provide the first direct evidence that in the early onset of sepsis, increased expression of C5aR occurs in thymocytes, which increases their susceptibility to C5a-induced apoptosis.

Key words: cecal ligation/puncture $\bullet$ caspases $\bullet$ thymus $\bullet$ complement

$\mathrm{T}$

The complement activation product, $\mathrm{C} 5 \mathrm{a}$, has been shown to play an important inflammatory role in rodents in the early phases of sepsis following cecal ligation/puncture (CLP) or after infusion of lipopolysaccharide (LPS) $(1,2)$. Besides its strong chemotactic activity, other effects are known, such as release from phagocytic cells of granular enzymes, production of superoxide anion, histamine release from mast cells, vasodilatation, increased vascular permeability, and smooth muscle contraction (3-7). The responses to $\mathrm{C} 5 \mathrm{a}$ are mediated by a pertussis toxin-sensitive G-protein-linked seven-transmembrane $\mathrm{C} 5 \mathrm{a}$ receptor $(\mathrm{C} 5 \mathrm{aR})$, which belongs to the superfamily of rhodopsin-type receptors $(8,9)$.

In recent years, the receptor for $\mathrm{C} 5 \mathrm{a}$ has been shown to be present in many different organs (e.g., liver, kidney, lungs, brain) (10-14), although $\mathrm{C} 5 \mathrm{aR}$ was originally considered to be confined to myeloid cells (15). Little is known about the functional importance of C5aR on nonmyeloid cells. During the development of sepsis, most organs undergo apoptosis, the thymus being especially sensitive to this process during sepsis $(16,17)$. We have recently reported that treatment of CLP rats with anti-C5a 
protects thymocytes from apoptosis, suggesting a direct or indirect role for $\mathrm{C} 5 \mathrm{a}$ in thymocyte apoptosis (18). A C5a or C5aR fragment with agonistic activity induces rapid elevation of nuclear c-fos in human neuroblastoma cells, resulting in DNA fragmentation $(19,20)$. Aside from these findings, there has been no other direct evidence for the ability of C5a to induce apoptosis. Therefore, we investigated changes in C5aR mRNA expression and ${ }^{125}$ I-C5a binding in rat thymocytes before and during sepsis, and the ability of exogenous $\mathrm{C} 5 \mathrm{a}$ to induce thymocyte apoptosis in vitro, after the induction of $\mathrm{C} 5 \mathrm{aR}$ in the onset of sepsis. Our findings provide direct evidence for the ability of $\mathrm{C} 5 \mathrm{a}$ to induce apoptosis in thymocytes, provided C5aR has been up-regulated.

\section{MATERIALS AND METHODS}

\section{Recombinant rat C5a and human C5a}

Recombinant human C5a (hu C5a) was obtained from Sigma (St. Louis, MO). Recombinant rat C5a (rrC5a) was produced in our laboratory, using the pGEX expression vector for GST gene fusion (Amersham Pharmacia Biotech, Piscataway, NJ) (18).

\section{Experimental sepsis induced by CLP}

Five- to eight-week-old specific pathogen-free male Long-Evans rats (Harlan, Indianapolis, IN) were used for all studies. Anesthesia was achieved by i.p. injection of Ketamine ( $20 \mathrm{mg} / 100 \mathrm{mg}$ body weight). In the CLP model, approximately one-third of the cecum was ligated through a $2-\mathrm{cm}$ abdominal midline incision. The ligated part of the cecum was punctured through with a 21-gauge needle. After repositioning of the bowel, the abdomen was closed in layers, using a 4.0 surgical suture (Ethicon, Somerville, NJ) and metallic clips. Sham animals underwent the same procedure without ligation or puncture of the cecum.

\section{Thymocyte isolation and in vitro stimulation}

At different time points $(0,3,6$, and $12 \mathrm{~h})$ following induction of CLP, animals were killed and the thymus was removed surgically immediately thereafter and placed on ice. Thymocytes were isolated according to the method of Morris et al. (21). After cell counting, the thymocyte suspension was diluted to 4-5 million cells $/ \mathrm{ml}$ using Dulbecco's modified Eagle's medium (DMEM) (BioWhittaker, Walkersville, MD) containing $0.1 \%$ bovine serum albumin (BSA). Thymocytes were then stimulated with different concentrations of rat or human C5a, LPS, or IL-6 at $37^{\circ} \mathrm{C}$.

\section{Binding studies}

rrC5a was labeled with ${ }^{125} \mathrm{I}$, using the chloramine method, as described previously (22). This protocol allowed gentle oxidation and resulted in intact chemotactic activity for the C5a preparation (23). Rat thymocytes were isolated (as previously described) and suspended in microcentrifuge tubes (1.5 $\mathrm{ml})$ in the binding buffer Hanks' balanced salt solution (HBSS) and $0.1 \%$ BSA at a final concentration of $4 \times$ $10^{7}$ cells $/ \mathrm{ml}$. The cell suspensions $(200 \mu \mathrm{l})$ were then incubated at $4{ }^{\circ} \mathrm{C}$ for $20 \mathrm{~min}$ in the presence of ${ }^{125} \mathrm{I}$ rrC5a (specific activity of $30-40 \mu \mathrm{Ci} / \mu \mathrm{g}$ ). The cell suspension was then layered over $20 \%$ sucrose and sedimented by centrifugation $(11,000 \mathrm{~g})$ in a swinging bucket rotor for $2 \mathrm{~min}$. After centrifugation, the tubes were frozen at $-80^{\circ} \mathrm{C}$, and the tips (containing the cell pellets) were cut off to determine the cell- 
bound ${ }^{125}$ I-rrC5a, using a gamma counter (1261 Multi $\gamma$, Wallace, Gaithersburg, MD). Results were then expressed as counts per minute, as a function of the concentration of ${ }^{125} \mathrm{I}-\mathrm{rrC} 5 \mathrm{a}$, in order to establish the saturation curve.

\section{RNA isolation and detection of C5aR mRNA by reverse transcriptase-polymer chain reaction (RT-PCR)}

Total RNA was isolated with the Trizol method (Life Technologies, Rockville, MD) according to the manufacturer's directions. Freshly isolated thymocytes were stimulated with LPS and IL-6 at various concentrations for $2 \mathrm{~h}$ at $37^{\circ} \mathrm{C}$ before total RNA was isolated. RNA was also isolated from thymocytes from rats 3, 6, and $12 \mathrm{~h}$ after induction of CLP. Digestion of any contaminating DNA was achieved by treatment with RQ1 Rnase-free DNase (Promega, Madison, WI).

Reverse transcription was performed with $1 \mu \mathrm{g}$ RNA, using the Superscript II RNase $\mathrm{H}^{-}$Reverse Transcriptase (Gibco BRL, Grand Island, NY) according to the manufacturer's protocol. PCR was then performed with primers for C5aR: 5' primer 5'-TAT AGT CCT GCC CTC GCT CAT-3' and 3' primer 5'-TCA CCA CTT TGA GCG TCT TGG-3'. The primers were designed for a 409-bp cDNA amplification in the middle region of the rat C5a receptor cDNA (position 373 to 781). The primers for the "housekeeping" gene GAPDH were 5' primer 5'-GCC TCG TCT CAT AGA CAA GAT G-3' and 3' primer 5'-CAG TAG ACT CCA CGA CAT AC-3'. After a "hot start" for $5 \mathrm{~min}$ at $94^{\circ} \mathrm{C}, 35$ cycles were used for amplification with a melting temperature of $94^{\circ} \mathrm{C}$, an annealing temperature of $60^{\circ} \mathrm{C}$, and an extending temperature of $72^{\circ} \mathrm{C}$, each for $1 \mathrm{~min}$, followed by a final extension at $72^{\circ} \mathrm{C}$ for 8 min. The RT-PCR product was confirmed by electrophoresis of samples in 1.2\% agarose gel. Control experiments were performed with the samples in which RT was not added to rule out contaminating DNA being responsible for results. PCR was performed from rat thymocyte mRNA, using different cycle numbers for $\mathrm{C} 5 \mathrm{aR}$ and GAPDH, to ensure that DNA was detected within the linear part of the amplifying curves for both primers.

\section{Apoptosis assay and flow cytometry}

Thymocyte apoptosis was detected using the Annexin V Fluos staining kit (Boehringer Mannheim, Indianapolis, IN) according to the manufacturer's instructions. In this assay, Annexin $\mathrm{V}(\mathrm{Ax})$ is conjugated to FITC and propidium iodide (PI). Approximately $4 \times 10^{6}$ cells $/ \mathrm{ml}$ were used for each assay. After they were stained for $12 \mathrm{~min}$, the cells were immediately placed on ice and analyzed with a flow cytometer (Coulter, Miami, FL), using 488-nm excitation and a 525-nm bandpass filter for FITC and a $620 \mathrm{~nm}$ filter for PI detection. Data were then analyzed with WinList computer software (Verity, Topsham, ME). Electronic compensation of the instrument was carried out to exclude overlapping areas of the two emission spectra. Cell debris was eliminated by gating according to side-scatter and forwardscatter detection. The regions for Ax-positive only, PI-positive only, double-positive, and doublenegative cells were created by using single-parameter analysis with Ax-FITC or PI.

\section{Caspase activity assay}

Caspase 3, 6, and 8 activities were measured by a fluorometric assay (Santa Cruz Biotechnology, Santa Cruz, CA) according to the manufacturer's instructions. In brief, thymocytes were isolated $3 \mathrm{~h}$ after CLP and then stimulated with nothing, with huC5a, or with $\operatorname{rrC} 5 \mathrm{a}$ at $37^{\circ} \mathrm{C}$ for $3 \mathrm{~h}$. Cell lysates from $8 \times 10^{6}$ 
thymocytes were incubated with the following caspase substrates (50 $\mu \mathrm{M}$ final concentration): AcDEVD-AFC (caspase 3), Ac-VEID-AFC (caspase 6), and Ac-IETD-AFC (caspase 8). After the cell lysates were incubated at $37^{\circ} \mathrm{C}$, free AFC (7-amino-4-trifluoromethyl coumarin) was detected on a Cytofluor II plate reader (Millipor, Bedford, MA) with a 400-nm excitation and a 505-nm emission filter. Caspase activation was expressed as the relative increase compared with the control values from nonstimulated thymocytes.

\section{RESULTS}

\section{Binding of ${ }^{125}$ I-rrC5a on thymocytes}

To detect $\mathrm{C} 5 \mathrm{aR}$ in rat thymocytes from normal rats, we used binding experiments with ${ }^{125} \mathrm{I}-\mathrm{rrC} 5 \mathrm{a}$ as described previously. Figure $1 \mathrm{~A}$ shows the saturation curve, using $1-1000 \mathrm{pM}{ }^{125} \mathrm{I}-\mathrm{rrC} 5 \mathrm{a}$. Nonspecific binding was assessed in the presence of 50-fold excess of nonlabeled $\operatorname{rrC5a}$ for the different concentrations of ${ }^{125} \mathrm{I}-\mathrm{rrC} 5 \mathrm{a}$. Saturation was reached at $\sim 500 \mathrm{pM}$. With increasing amounts of nonlabeled rrC5a, binding of ${ }^{125} \mathrm{I}-\mathrm{rrC} 5 \mathrm{a}$ to thymocytes could be competed against, as demonstrated in Figure 1B. Between $10^{-14}$ and $10^{-11} \mathrm{M}$ nonlabeled rC5a, the binding signal achieved with 200 pmol ${ }^{125} \mathrm{I}$ rrC5a could be reduced by $\sim 50 \%$.

\section{Increased ${ }^{125}$ I-rrC5a binding to LPS- and IL-6-treated thymocytes and to thymocytes from CLP rats}

To determine whether enhanced binding of C5a occurred in rat thymocytes during the onset of sepsis, thymocytes were isolated $3 \mathrm{~h}$ after CLP and compared with normal thymocytes. Figure $2 \mathrm{~A}$ demonstrates significantly increased binding of ${ }^{125} \mathrm{I}-\mathrm{rrC} 5 \mathrm{a}$ to thymocytes obtained from rats $3 \mathrm{~h}$ after CLP. To further investigate mediators possibly responsible for these results, we isolated thymocytes from normal rats and stimulated them in vitro with LPS and IL-6 at various concentrations for $3 \mathrm{~h}$ at $37^{\circ} \mathrm{C}$, because these agonists are known to cause increased expression of $\mathrm{C} 5 \mathrm{aR}$ in rat hepatocytes (10). Figures $2 \mathrm{~B}$ and $\underline{2 \mathrm{C}}$ demonstrate that each mediator, in a dose-dependent manner, was capable of significantly increasing

${ }^{125} \mathrm{I}-\mathrm{rrC} 5 \mathrm{a}$ binding to thymocytes. At concentrations of $100 \mathrm{ng} / \mathrm{ml} \mathrm{IL-6}$ and $500 \mathrm{ng} / \mathrm{ml} \mathrm{LPS}$, binding appeared to be maximally increased.

\section{Detection of mRNA for C5aR with RT-PCR}

To assess changes in mRNA for $\mathrm{C} 5 \mathrm{aR}$ in rat thymocytes and assess conditions that might cause its increase, we performed RT-PCR experiments for C5aR mRNA as described previously. mRNA for $\mathrm{C} 5 \mathrm{aR}$ in thymocytes obtained from normal rats could be faintly detected in the absence of any other manipulation (Fig. 3A, lane 1, ctrl). Thirty-five cycles of amplification were required to detect a faint band, suggesting a fairly low copy number of C5aR mRNA under these conditions. To investigate whether C5aR could be induced in thymocytes after exposure to bacterial endotoxin (LPS) or to IL-6, we incubated thymocytes from normal rats, with LPS (1-100 ng/ml) from Escherichia coli or with recombinant rat IL-6 (1-100 ng/ml) for $2 \mathrm{~h}$ at $37^{\circ} \mathrm{C}$. Figure $3 \mathrm{~A}$ shows the dose-dependent increases in mRNA for C5aR. Compared with nonstimulated (ctrl) thymocytes, LPS at $1 \mathrm{ng} / \mathrm{ml}$ and IL-6 at 100 $\mathrm{ng} / \mathrm{ml}$ clearly increased expression of $\mathrm{C} 5 \mathrm{aR}$ mRNA within $2 \mathrm{~h}$ of stimulation. Above a concentration of $1 \mathrm{ng} \mathrm{LPS} / \mathrm{ml}$, there was a progressive reduction in mRNA for C5aR, whereas with IL-6, there was a progressive increase in expression from 1 to $100 \mathrm{ng}$ IL-6/ml. 
To address the question of whether mRNA of C5aR is induced in thymocytes during sepsis, we isolated thymocyte RNA at 3, 6, and $12 \mathrm{~h}$ after CLP. The copy number for C5aR mRNA was clearly increased as early as $3 \mathrm{~h}$ after CLP (Fig. 3, lower frame, lane 2), suggesting rapid up-regulation of C5aR in the early period of sepsis. After $6 \mathrm{~h}$, the increase in C5aR mRNA was similar to the findings at the 3-h time point. However, $12 \mathrm{~h}$ after induction of CLP, the increase of mRNA for C5aR was even more intense. This is a time when thymocyte apoptosis is well advanced $(18,25)$. These data indicate that mRNA for C5aR is increased in the early period of CLP-induced sepsis and that C5aR protein is correspondingly increased, as indicated by increased ${ }^{125} \mathrm{I}-\mathrm{C} 5 \mathrm{a}$ binding.

\section{Induction by C5a of thymocyte apoptosis}

Because we were recently able to show that anti-C5a treatment could successfully reduce thymocyte apoptosis during sepsis (18), we investigated whether thymocyte apoptosis could be induced by direct exposure to $\mathrm{C} 5 \mathrm{a}$ under conditions in which $\mathrm{C} 5 \mathrm{aR}$ expression has been increased. Rats were sacrificed, and thymocytes were obtained at various time points $(0,2,3,6,12$, and $24 \mathrm{~h})$ after CLP. They were then incubated with either human $\mathrm{C} 5 \mathrm{a}$ or $\operatorname{rrC} 5 \mathrm{a}$ (at $37^{\circ} \mathrm{C}$ for $0.5,1.0$, or $2.0 \mathrm{~h}$ ). Apoptosis was measured by binding of annexin- $\mathrm{V}$ to thymocytes, as determined by flow cytometry. Preliminary experiments showed significant apoptosis in thymocytes obtained 2 and $3 \mathrm{~h}$ after CLP, after incubation with huC5a or $\operatorname{rrC5a}$ for $30 \mathrm{~min}$ at $37^{\circ} \mathrm{C}$ (data not shown). For time points beyond $3 \mathrm{~h}$ following CLP, the extent of apoptosis was already too advanced to detect any effect of added C5a (data not shown). Using thymocytes 2 or $3 \mathrm{~h}$ after CLP, we conducted experiments, stimulating thymocytes with different concentrations of huC5a and $\mathrm{rrC5}$ a (between 1 and $200 \mathrm{nM}$ ). The strongest apoptotic outcome resulted from $100 \mathrm{nM} \mathrm{huC5a}$ and $30 \mathrm{nM} \mathrm{rC5a}$. Figure 4A summarizes the increase in apoptosis and necrosis of thymocytes after the addition of $30 \mathrm{nM}$ rC5a or $100 \mathrm{nM}$ huC5a relative to no addition of C5a ("none"), using thymocytes 2 or $3 \mathrm{~h}$ after the onset of CLP. Figure 4B shows the results of a typical flow cytometry experiment. Exposure to either huC5a or rrC5a induced apoptosis of thymocytes from CLP rats, but not from normal rats (data not shown).

\section{C5a-induced activation of caspases in thymocytes}

To extend the findings described previously, we investigated the ability of C5a to induce caspase activity in thymocytes. Thymocytes were isolated from rats $3 \mathrm{~h}$ after induction of CLP and then incubated at $37^{\circ} \mathrm{C}$ with $100 \mathrm{nM}$ huC5a or $30 \mathrm{nM} \mathrm{rrC5a}$ or in the absence of C5a for 30 minutes. Afterwards, cells were lysed, and lysates were incubated with the fluorescently tagged substrates. Enzymatic activity was detected by increases in cleavage of caspase substrates, as determined by fluorometry. Results were expressed as relative increases compared to the non-stimulated control group. Figure 5 shows the results of a representative experiment in which each sample was assayed in triplicate. In terms of increasing caspases 3, 6, and 8 activity, $30 \mathrm{nM}$ rrC5a was more effective than $100 \mathrm{nM}$ huC5a. In the case of caspases 3 and 6 , the increase was $40 \%$ and $37 \%$, respectively, following the addition of rrC5a stimulation. Caspase 8 activity was very low in general, but thymocyte contact with

rrC5a caused it to increase by $27 \%$. In thymocytes from normal rats, incubation with $\operatorname{rrC} 5 \mathrm{a}(30 \mathrm{nM})$ or huC5a (100 nM) did not result in caspase activation (data not shown). 


\section{DISCUSSION}

There is increasing evidence that C5a may play an important role in events linked to the early stages of experimental sepsis, as shown by protective effects of anti-C5a $(2,24-26)$. In these studies, anti-C5a treatment was instituted in the early period (1-6 hours) after CLP to achieve protective effects. These studies suggested that many of the pathophysiological changes in experimental sepsis could be ascribed to early production of $\mathrm{C} 5 \mathrm{a}$. As mentioned previously, $\mathrm{C} 5 \mathrm{a}$ is responsible for many pathophysiological changes (3-7). These effects are achieved through the interaction of C5a with a seven-transmembrane G-protein-linked C5aR, which was originally detected in myeloid cells (15) and has now been detected in several different organs (10-14). On the basis of recent studies in rodents, C5a is considered to play an important role in the early phases of CLP-induced sepsis (27). We recently demonstrated a dramatically protective effect of anti-C5a treatment on thymocyte apoptosis during CLP-induced sepsis (18). In these studies, we were not successful in inducing apoptosis in vitro by incubation of normal thymocytes (rat) with $\mathrm{rC} 5 \mathrm{a}$. We therefore measured in thymocytes the presence of mRNA for C5aR and binding of ${ }^{125} \mathrm{I}$-labeled $\mathrm{C} 5 \mathrm{a}$, because currently no available antibody will detect rat C5aR protein. C5aR protein has been described in human T cells (28).

Binding studies have shown specific, saturable, and high affinity binding of C5a to rat thymocytes (Fig. 1), implying the presence of $\mathrm{C} 5 \mathrm{aR}$, even though its density on thymocytes is probably low. When thymocytes from normal rats were stimulated in vitro with LPS or IL-6, binding of ${ }^{125}$ I-rrC5a increased significantly. Thymocytes from rats $3 \mathrm{~h}$ after CLP also showed significantly increased binding. These data provide evidence that $\mathrm{C} 5 \mathrm{aR}$ is present on thymocytes and that it is up-regulated during the development of sepsis, perhaps by mediators that are known to play an important role during the onset of sepsis in the CLP model.

We extended our findings by RT-PCR experiments to evaluate C5aR mRNA. We found in thymocytes from normal rats that the copy number of mRNA for C5aR was very low. With 35 amplification cycles, it was possible to find a weak band, as detected in 3 (out of 10) separate experiments. C5aR mRNA levels in normal thymocytes rose appreciably after $2 \mathrm{~h}$ of stimulation with IL-6 or LPS. It is interesting that at higher LPS concentrations, mRNA levels for C5aR fell, perhaps due to unstable mRNA. In contrast, in vitro incubation of thymocytes with IL-6 showed a direct dose-response relationship for mRNA for C5aR. Because IL-6 is known to be up-regulated at the onset of CLP-induced sepsis (27), we investigated whether mRNA for $\mathrm{C} 5 \mathrm{aR}$ in thymocytes was increased during sepsis. We were able to show that, as early as $3 \mathrm{~h}$ following CLP, there was clearly increased mRNA for C5aR on thymocytes ( $\underline{\text { Fig. } 3})$ and that this was associated with increased binding of C5a to thymocytes obtained $3 \mathrm{~h}$ after CLP (Fig. 2), strongly implying up-regulation of C5aR during sepsis. The levels of C5aR mRNA were even more intense at $12 \mathrm{~h}$. Binding studies, together with the RT-PCR results, strongly suggest that C5aR is induced in the early onset of sepsis. An antibody to rat $\mathrm{C} 5 \mathrm{aR}$ is currently not available, precluding direct measurements of $\mathrm{C} 5 \mathrm{aR}$ protein on rat thymocytes.

To address the question of whether C5a can directly induce apoptosis in thymocytes under conditions in which the $\mathrm{C} 5 \mathrm{aR}$ is up-regulated, we investigated thymocyte apoptosis and thymocyte mRNA for C5aR in CLP animals at different time points. Previous studies have shown that a C5a or C5aR fragment with agonist activities induces apoptosis in human neuroblastoma cells $(19,20)$. We were able to show for the first time that C5a can directly induce apoptosis in thymocytes obtained 2 and $3 \mathrm{~h}$ after CLP in rats. In sham animals (operated but absent CLP), no such evidence could be found. Corticosteroids are known to 
induce apoptosis in thymocytes $(29,30)$, and Fas-ligand also plays an important role, in contrast to endotoxin and tumor necrosis factor $\alpha$, which are said to evoke no direct apoptotic response (31-33). The extent to which $\mathrm{C} 5 \mathrm{a}$ contributes to apoptosis during CLP requires additional investigation. Our recent studies have shown that treatment of CLP rats with anti-C5a greatly reduces the amount of thymocyte apoptosis (18). The data presented here show that C5a incubated with thymocytes obtained 2 $\mathrm{h}$ after CLP induced substantial levels of apoptosis. The extent of in vitro induction of apoptosis likely depends on the cell surface content of $\mathrm{C} 5 \mathrm{aR}$ that are not occupied by their ligand and internalized. We conducted experiments with a cyclic C5aR antagonist to block C5a-mediated thymocyte apoptosis in vitro. Unfortunately, this antagonist showed agonistic activity in our experiments and induced apoptosis in CLP thymocytes (data not shown). We can not rule out the possibility that a costimulatory mechanism may be involved in C5a-induced thymocyte apoptosis in vitro, possibly related to a "priming" of thymocytes during the onset of CLP-induced sepsis by proinflammatory mediators (e.g., LPS, cytokines).

We were able to demonstrate in CLP thymocytes that C5a induced increases in caspases 3,6 , and 8 enzymatic activities following thymocyte exposure to $\mathrm{rC} 5 \mathrm{a}$ or huC5a. Different caspases are activated in sepsis-induced thymocyte apoptosis $(18,34)$. A recent study has unexpectedly shown a neuroprotective effect of C5a mediated through caspase-3 inhibition (35). Our findings contrast with those of this study. Thymocyte apoptosis occurring during sepsis is thought to be beneficial in terms of reducing an overwhelming immune response (36), although the loss of lymphoid cells during sepsis is generally considered to lead to potentially threatening immunosuppression.

In this study, we provide evidence for the induction of $\mathrm{C} 5 \mathrm{aR}$ in rat thymocytes during sepsis, as demonstrated by C5aR RT-PCR and C5a binding studies. We also demonstrate the ability of IL-6 or LPS to cause similar changes in vitro in normal thymocytes. Under conditions in which C5aR is upregulated, C5a appears able to directly induce apoptosis in thymocytes. To our knowledge, this is the first time in CLP-induced sepsis, that $\mathrm{C} 5 \mathrm{aR}$ induction is demonstrated. Under these conditions, C5a can then directly induce apoptosis in thymocytes. This study suggests not only a new role for C5a in sepsis, but also the importance of $\mathrm{C} 5 \mathrm{aR}$ induction during sepsis. C5aR may well be a target for drug therapy to control undesirable apoptotic pathophysiological changes in the early stages of sepsis.

\section{ACKNOWLEDGMENTS}

This paper is supported by the following National Institutes of Health and National Heart, Lung, and Blood Institute grants: GM-29507, HL-31963, and GM-61656.

\section{REFERENCES}

1. Czermak, B. J., Sarma, V., Pierson, C. L., Warner, R. L., Huber-Lang, M., Bless, N. M., Schmal, H., Friedl, H. P., and Ward, P. A. (1999) Protective effects of C5a blockade in sepsis. Nat Med 5, 788-792

2. Smedegard, G., Cui, L. X., and Hugli, T. E. (1989) Endotoxin-induced shock in the rat. A role for C5a. Am J Pathol 135, 489-497 
3. Cochrane, C. G., and Muller-Eberhard, H. J. (1968) The derivation of two distinct anaphylatoxin activities from the third and fifth components of human complement. $J$ Exp Med 127, 371-386

4. Goldstein, I. M., and Weissmann, G. (1974) Generation of C5-derived lysosomal enzymereleasing activity (C5a) by lysates of leukocyte lysosomes. $J$ Immunol 113, 1583-1588

5. Sacks, T., Moldow, C. F., Craddock, P. R., Bowers, T. K., and Jacob, H. S. (1978) Oxygen radicals mediate endothelial cell damage by complement- stimulated granulocytes. An in vitro model of immune vascular damage. J Clin Invest 61, 1161-1167

6. Schumacher, W. A., Fantone, J. C., Kunkel, S. E., Webb, R. C., and Lucchesi, B. R. (1991) The anaphylatoxins $\mathrm{C} 3 \mathrm{a}$ and $\mathrm{C} 5 \mathrm{a}$ are vasodilators in the canine coronary vasculature in vitro and in vivo. Agents Actions 34, 345-349

7. Shin, H. S., Snyderman, R., Friedman, E., Mellors, A., and Mayer, M. M. (1968) Chemotactic and anaphylatoxic fragment cleaved from the fifth component of guinea pig complement. Science 162, 361-363

8. Gerard, N. P., and Gerard, C. (1991) The chemotactic receptor for human C5a anaphylatoxin. Nature 349, 614-617

9. Gerard, N. P., Hodges, M. K., Drazen, J. M., Weller, P. F., and Gerard, C. (1989) Characterization of a receptor for $\mathrm{C} 5 \mathrm{a}$ anaphylatoxin on human eosinophils. $\mathrm{J}$ Biol Chem 264, 1760-1766

10. Schieferdecker, H. L., Schlaf, G., Koleva, M., Gotze, O., and Jungermann, K. (2000) Induction of functional anaphylatoxin $\mathrm{C} 5$ a receptors on hepatocytes by in vivo treatment of rats with IL-6. J Immunol 164, 5453-5458

11. Wetsel, R. A. (1995) Expression of the complement C5a anaphylatoxin receptor (C5aR) on non-myeloid cells. Immunol Lett 44, 183-187

12. Zwirner, J., Fayyazi, A., and Gotze, O. (1999) Expression of the anaphylatoxin C5a receptor in non-myeloid cells. Mol Immunol 36, 877-884

13. Floreani, A. A., Heires, A. J., Welniak, L. A., Miller-Lindholm, A., Clark-Pierce, L., Rennard, S. I., Morgan, E. L., and Sanderson, S. D. (1998) Expression of receptors for C5a anaphylatoxin (CD88) on human bronchial epithelial cells: enhancement of C5a-mediated release of IL-8 upon exposure to cigarette smoke. J Immunol 160, 5073-5081

14. Haviland, D. L., McCoy, R. L., Whitehead, W. T., Akama, H., Molmenti, E. P., Brown, A., Haviland, J. C., Parks, W. C., Perlmutter, D. H., and Wetsel, R. A. (1995) Cellular expression of the $\mathrm{C} 5 \mathrm{a}$ anaphylatoxin receptor $(\mathrm{C} 5 \mathrm{aR})$ : demonstration of $\mathrm{C} 5 \mathrm{aR}$ on nonmyeloid cells of the liver and lung. J Immunol 154, 1861-1869 
15. Chenoweth, D. E., hugli, T.E. (1978) Demonstration of specific C5a receptor on intact human polymorphonuclear leukocytes. Pro. Natl. Acad. Sci USA 75, 3943-3947

16. Wang, S. D., Huang, K. J., Lin, Y. S., and Lei, H. Y. (1994) Sepsis-induced apoptosis of the thymocytes in mice. J Immunol 152, 5014-5021

17. Barke, R. A., Roy, S., Chapin, R. B., and Charboneau, R. (1994) The role of programmed cell death (apoptosis) in thymic involution following sepsis. Arch Surg 129, 1256-1261; discussion 1261-1252

18. Guo, R. F., Huber-Lang, M., Wang, X., Sarma, V., Padgaonkar, V. A., Craig, R. A., Riedemann, N. C., McClintock, S. D., Hlaing, T., Shi, M. M., and Ward, P. A. (2000) Protective effects of anti-C5a in sepsis-induced thymocyte apoptosis. J Clin Invest 106, $1271-1280$

19. Farkas, I., Baranyi, L., Liposits, Z. S., Yamamoto, T., and Okada, H. (1998) Complement C5a anaphylatoxin fragment causes apoptosis in TGW neuroblastoma cells. Neuroscience 86, 903-911

20. Farkas, I., Baranyi, L., Takahashi, M., Fukuda, A., Liposits, Z., Yamamoto, T., and Okada, H. (1998) A neuronal C5a receptor and an associated apoptotic signal transduction pathway. J Physiol 507, 679-687

21. Morris, I. D., Lendon, R. G., Waters, C., Naylor, G., and Jones, N. (1997) Thymic regression and apoptosis in the rat after treatment with the Leydig cell cytotoxin ethylene dimethanesulphonate (EDS). Toxicology 120, 19-27.

22. Bennett, G. L., and Horuk, R. (1997) Iodination of chemokines for use in receptor binding analysis. Methods Enzymol 288, 134-148

23. Lacy, M., Jones, J., Whittemore, S. R., Haviland, D. L., Wetsel, R. A., and Barnum, S. R. (1995) Expression of the receptors for the C5a anaphylatoxin, interleukin- 8 and FMLP by human astrocytes and microglia. J Neuroimmunol 61, 71-78

24. Huber-Lang, M. S., Sarma, J. V., McGuire, S. R., Lu, K. T., Guo, R. F., Padgaonkar, V. A., Younkin, E. M., Laudes, I. J., Riedemann, N. C., Younger, J. G., and Ward, P. A. (2001) Protective effects of anti-C5a peptide antibodies in experimental sepsis. FASEB J 15, 568570

25. Huber-Lang, M., Sarma, V. J., Lu, K. T., McGuire, S. R., Padgaonkar, V. A., Guo, R. F., Younkin, E. M., Kunkel, R. G., Ding, J., Erickson, R., Curnutte, J. T., and Ward, P. A. (2001) Role of C5a in multiorgan failure during sepsis. J Immunol 166, 1193-1199

26. Stevens, J. H., O'Hanley, P., Shapiro, J. M., Mihm, F. G., Satoh, P. S., Collins, J. A., and Raffin, T. A. (1986) Effects of anti-C5a antibodies on the adult respiratory distress syndrome in septic primates. J Clin Invest 77, 1812-1816 
27. Villa, P., Sartor, G., Angelini, M., Sironi, M., Conni, M., Gnocchi, P., Isetta, A. M., Grau, G., Buurman, W., van Tits, L. J., and et al. (1995) Pattern of cytokines and pharmacomodulation in sepsis induced by cecal ligation and puncture compared with that induced by endotoxin. Clin Diagn Lab Immunol 2, 549-553

28. Nataf, S., Davoust, N., Ames, R. S., and Barnum, S. R. (1999) Human T cells express the C5a receptor and are chemoattracted to C5a. J Immunol 162, 4018-4023

29. Stefanelli, C., Bonavita, F., Stanic, I., Farruggia, G., Falcieri, E., Robuffo, I., Pignatti, C., Muscari, C., Rossoni, C., Guarnieri, C., and Caldarera, C. M. (1997) ATP depletion inhibits glucocorticoid-induced thymocyte apoptosis. Biochem J 322, 909-917

30. Izawa, M., Kato, Y., and Iwasaki, K. (1997) Induction of a receptor-mediated genomic DNA fragmentation in rat thymus following administration of glucocorticoids with different biopotencies: an approach by a cell-free system. Endocr J 44, 677-686

31. Hiramatsu, M., Hotchkiss, R. S., Karl, I. E., and Buchman, T. G. (1997) Cecal ligation and puncture (CLP) induces apoptosis in thymus, spleen, lung, and gut by an endotoxin and TNFindependent pathway. Shock 7, 247-253

32. Ayala, A., Chung, C. S., Xu, Y. X., Evans, T. A., Redmond, K. M., and Chaudry, I. H. (1999) Increased inducible apoptosis in CD4+ T lymphocytes during polymicrobial sepsis is mediated by Fas ligand and not endotoxin. Immunology 97, 45-55

33. Ayala, A., Xu, Y. X., Chung, C. S., and Chaudry, I. H. (1999) Does Fas ligand or endotoxin contribute to thymic apoptosis during polymicrobial sepsis? Shock 11, 211-217

34. Tinsley, K. W., Cheng, S. L., Buchman, T. G., Chang, K. C., Hui, J. J., Swanson, P. E., Karl, I. E., and Hotchkiss, R. S. (2000) Caspases-2, -3, -6, and -9, but not caspase-1, are activated in sepsis-induced thymocyte apoptosis. Shock 13, 1-7

35. Mukherjee, P., and Pasinetti, G. M. (2001) Complement anaphylatoxin C5a neuroprotects through mitogen-activated protein kinase-dependent inhibition of caspase 3. J Neurochem 77, 43-49

36. Hotchkiss, R. S., Swanson, P. E., Cobb, J. P., Jacobson, A., Buchman, T. G., and Karl, I. E. (1997) Apoptosis in lymphoid and parenchymal cells during sepsis: findings in normal and T- and B-cell-deficient mice. Crit Care Med 25, 1298-1307 
Fig. 1
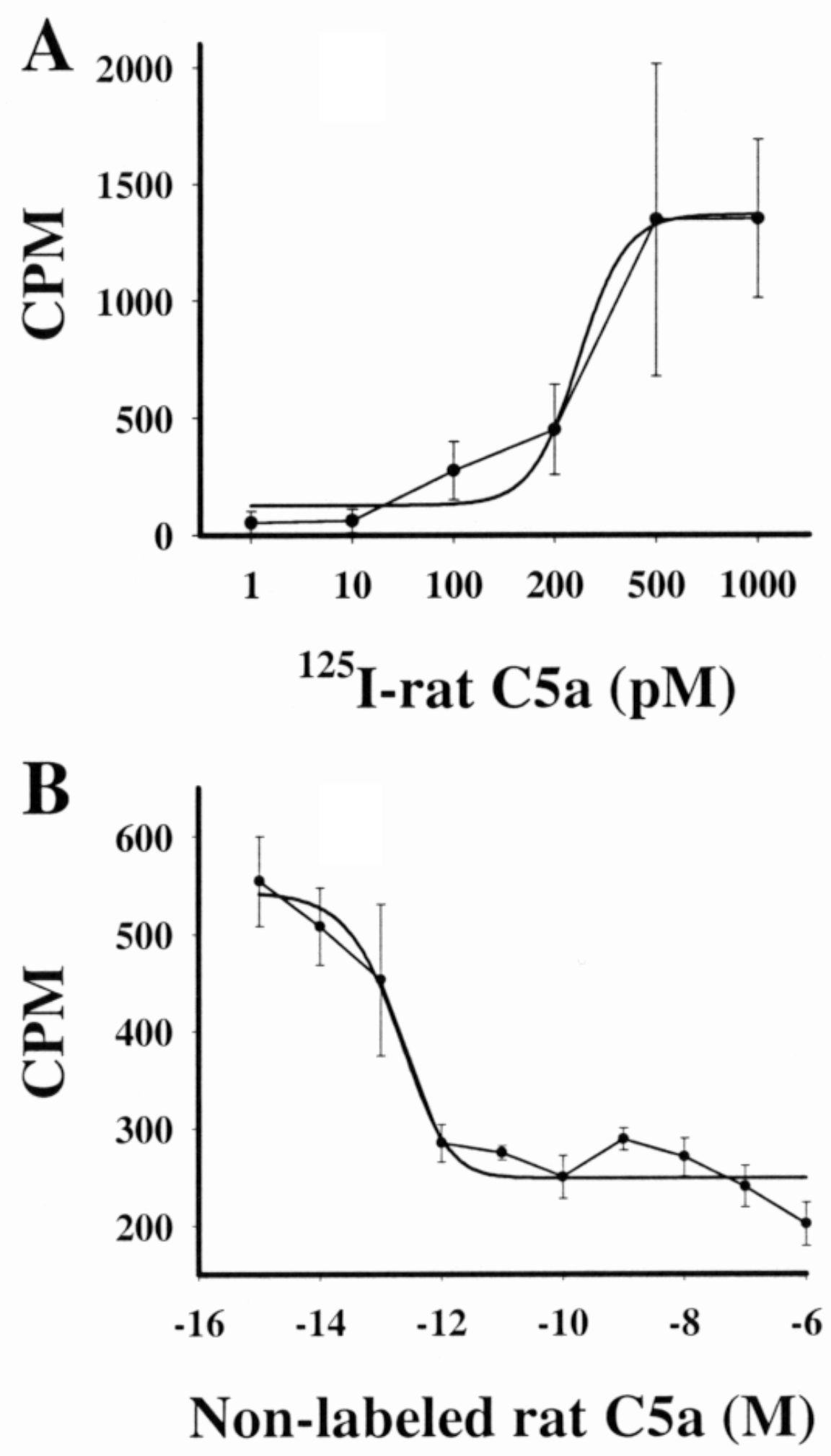

Figure 1. ${ }^{125}$ I-rrC5a binding to thymocytes from normal rats, expressed as counts per minute (CPM). A) Binding saturation occurred at $\sim 1 \mathrm{nM}$. B) Competition of binding achieved with $200 \mathrm{pM}^{125} \mathrm{I}$-rrC5a by increasing amounts of nonlabeled rrC5a. Competition was achieved between $10^{-14}$ and $10^{-10}$ M C5a. Results are from three to nine independent experiments carried out for each data point, which represents quadruplicate samples. 
Fig. 2
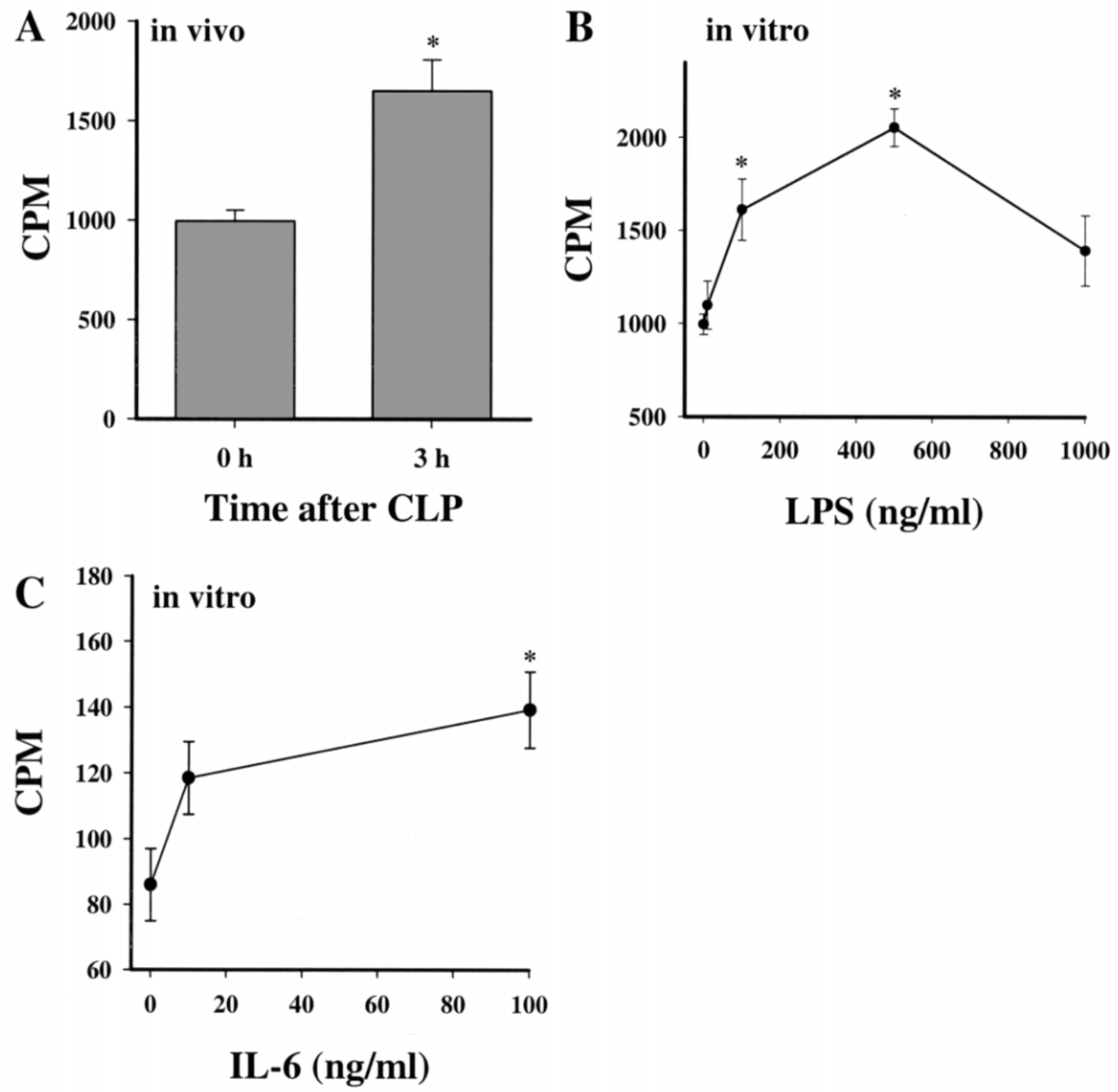

Figure 2. ${ }^{125} \mathrm{I}-\mathrm{rrC5}$ a binding to rat thymocytes obtained $3 \mathrm{~h}$ after cecal ligation/puncture (CLP) (A) and after lipopolysaccharide (LPS) or IL-6 stimulation in vitro (B, C). *Significantly increased binding compared with the nonstimulated controls. Data are representative of three to six independent experiments, carried out in quadruplicate samples. 
Fig. 3

A In vitro

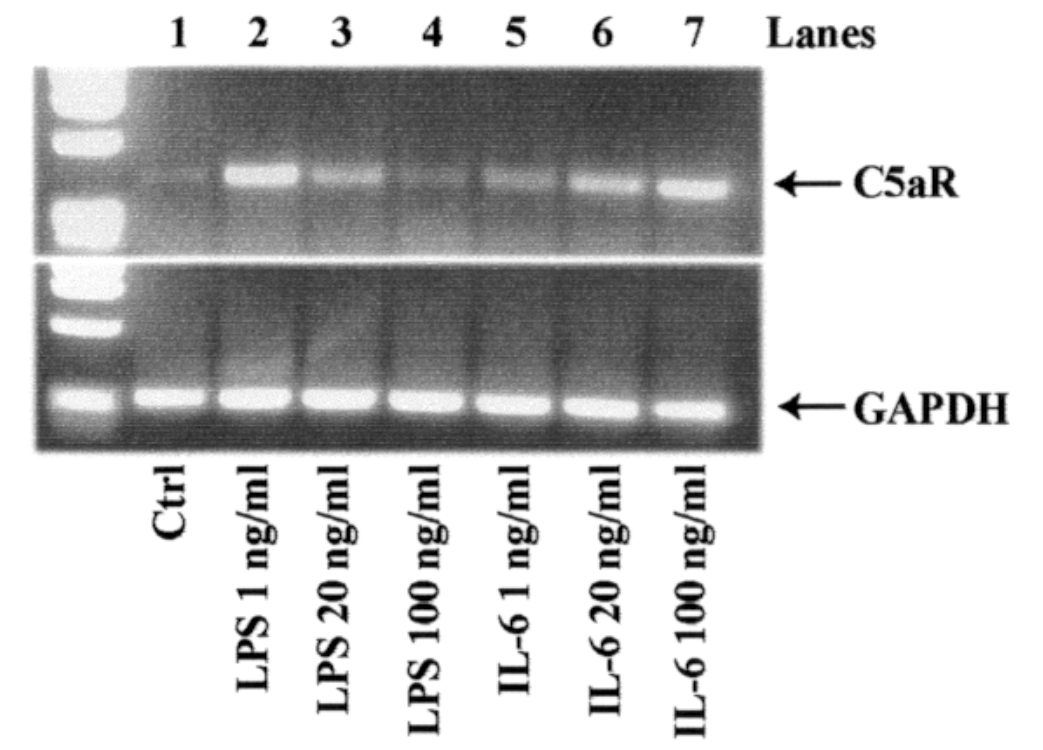

\section{B In vivo}
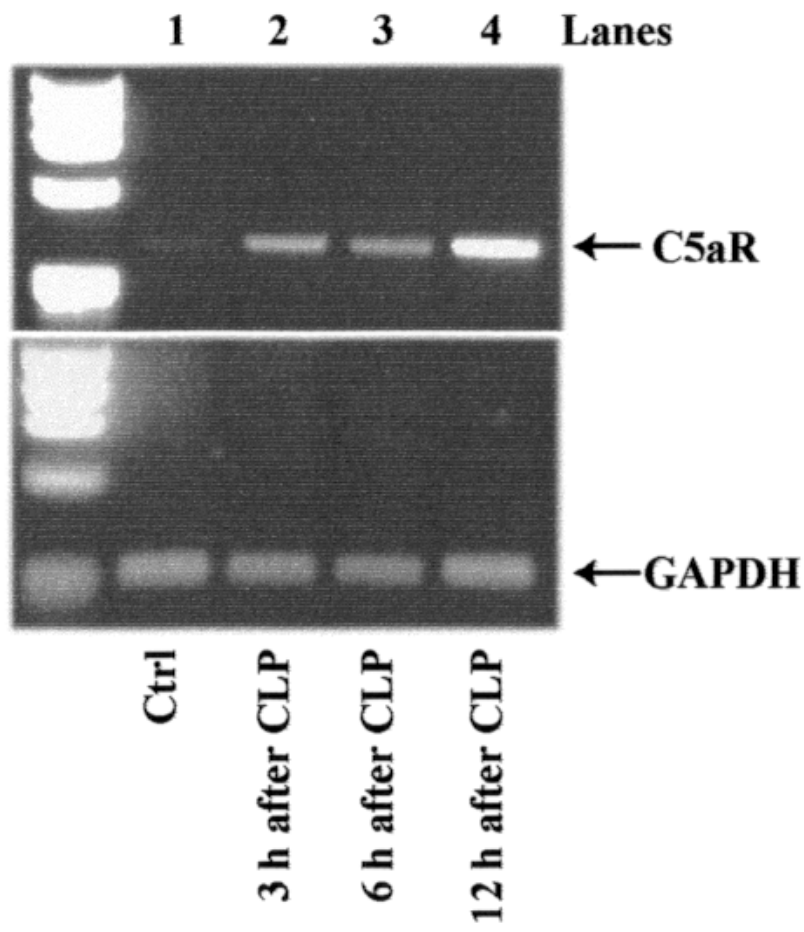

Figure 3. Semiquantitative reverse transcriptase-polymer chain reaction analysis for C5aR mRNA in rat thymocytes. A) Thymocytes from normal rats were stimulated with lipopolysaccharide (LPS) and IL-6 in vitro at different concentrations. B) Induction of C5aR mRNA in vivo as early as $3 \mathrm{~h}$ and as long as 6 and $12 \mathrm{~h}$ after cecal ligation/puncture (CLP). Equal loading conditions were demonstrated with bands for GAPDH-mRNA production (lower panels in both frames). Data are representative of results from two independent experiments. 
Fig. 4

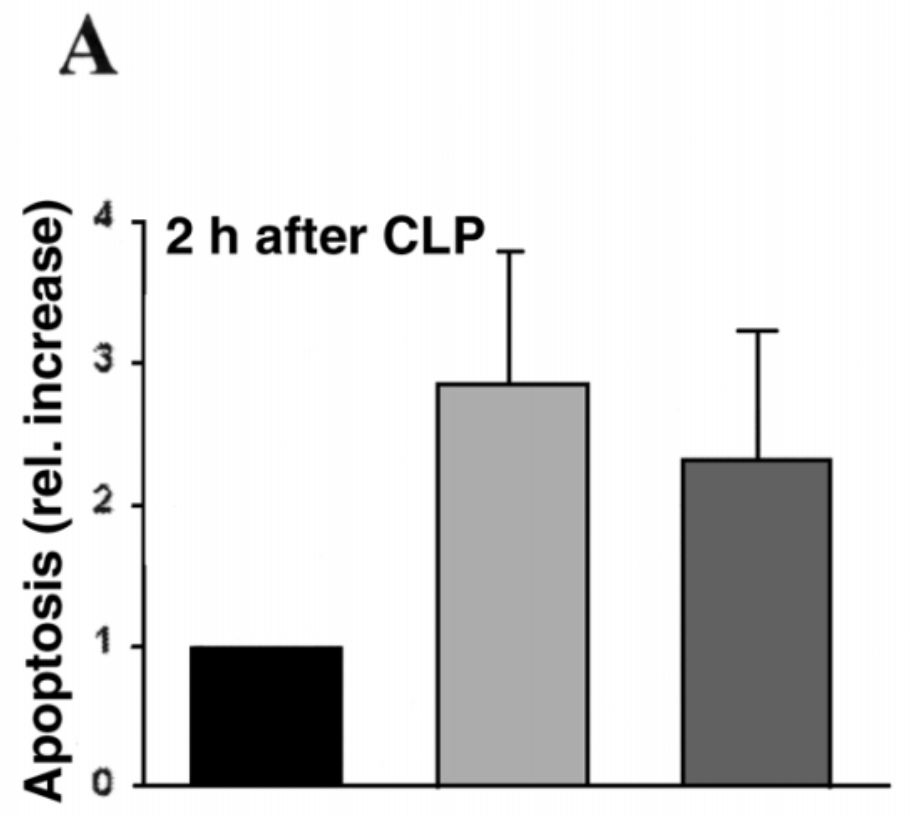

B

\section{$2 \mathrm{~h}$ after CLP}

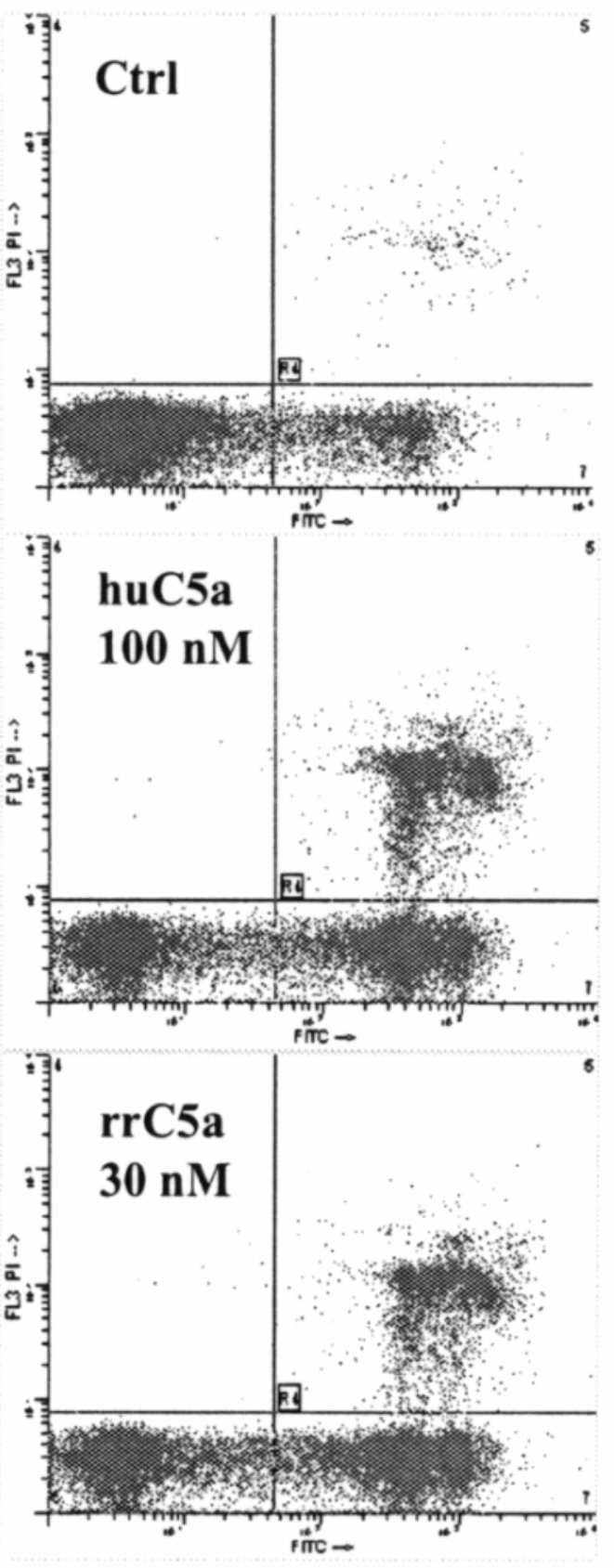

\section{Annexin-V binding (MCF)}

Figure 4. Flow cytometry analysis for apoptosis (annexin-V binding) in rat thymocytes. A) Rat thymocytes were isolated 2 and $3 \mathrm{~h}$ after cecal ligation/puncture (CLP) and not otherwise stimulated or incubated with huC5a (100 nM) or rrC5a $(30 \mathrm{nM})$ for $30 \mathrm{~min}$ at $37^{\circ} \mathrm{C}$. Flow cytometry was performed after staining with annexin-V for $15 \mathrm{~min}$. Data are presented as increases in apoptosis relative to the corresponding control value in each experiment. Data are from three to nine independent experiments per bar graph. B) Flow cytometric data from thymocytes obtained from rats $2 \mathrm{~h}$ after CLP and not otherwise stimulated or after exposure to huC5a or $\operatorname{rrC} 5 \mathrm{a}\left(30 \mathrm{~min}\right.$ at $\left.37^{\circ} \mathrm{C}\right)$. 
Fig. 5

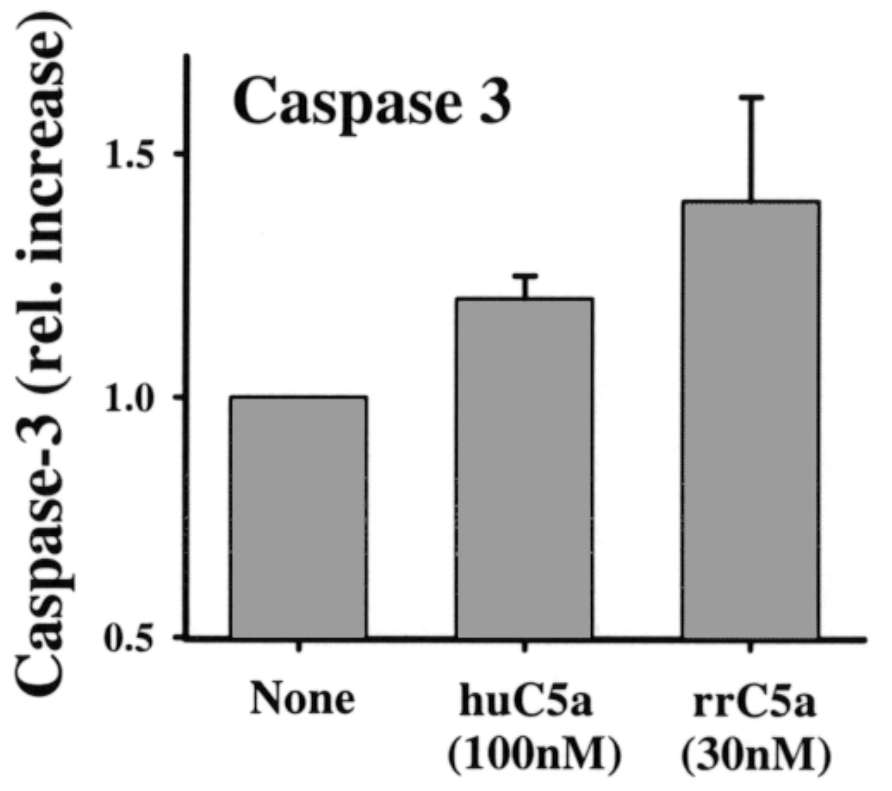

Additives

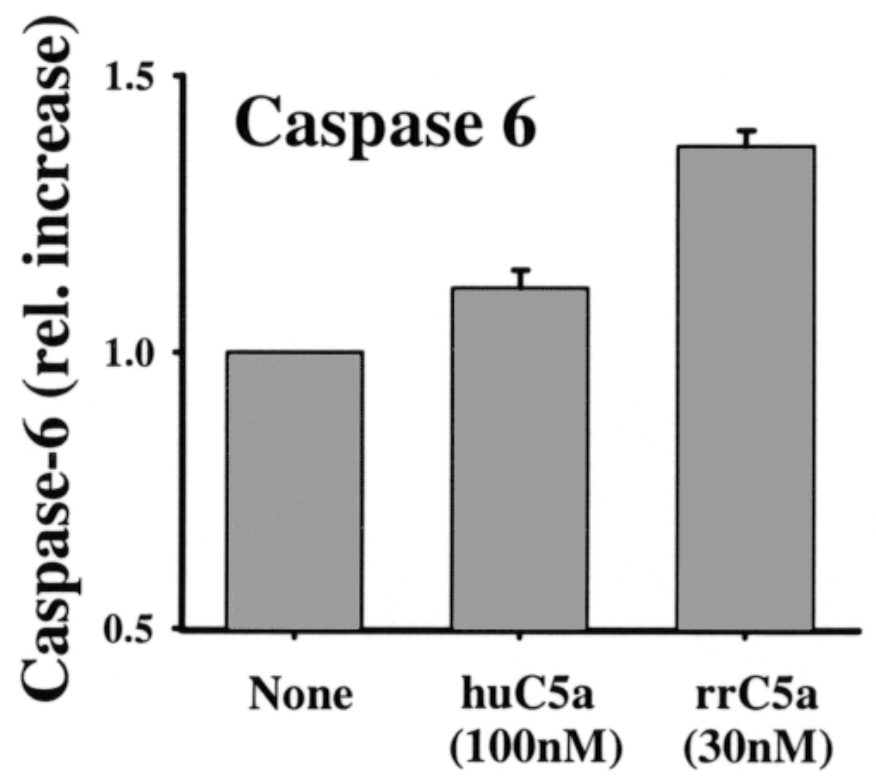

Additives

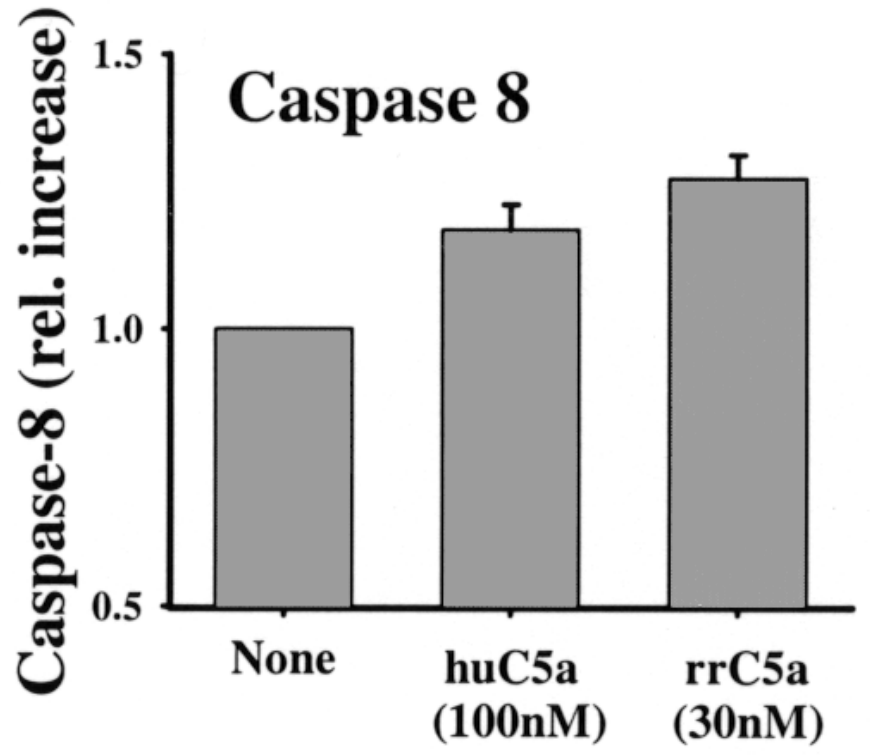

\section{Additives}

Figure 5. Caspase-activation in thymocytes obtained $3 \mathrm{~h}$ after cecal ligation/puncture (CLP), after addition of huC5a or rrC5a. Enzymatic assays for caspases were used. Shown are relative (\%) increases in caspase activities compared with the corresponding activities of nonstimulated thymocytes for each condition. The results are representative of data from two independent experiments, with each condition evaluated in quadruplicate. 